\title{
Comparative Height Growth of Eastern Larch and Black Spruce in Northwestern Ontario
}

\author{
Douglas A. Mead \\ Assistant Professor \\ School of Forestry \\ Lakehead University
}

\begin{abstract}
Height growth of eastern larch (Larix laricina (Du Roi) K. Koch) and black spruce (Picea mariana (Mill.) B.S.P.) was determined using standard stem analysis methods on trees from two sites in northwestern Ontario. The data were obtained from mixed larch-spruce stands which were relatively undisturbed. The larch exhibited substantially better height growth than the spruce through age 65 .
\end{abstract}

\section{Résumé}

On a déterminé la croissance en hauteur du mélèze laricin (Larix laricina (Du Roi) K. Koch) et de l'épinette noire (Picea mariana (Mill.) B.S.P.) en se servant de méthodes courantes d'analyse de tige d'arbres provenant de deux stations du nord-ouest de l'Ontario. Les données ont été cueillies dans des peuplements composés de mélèzes et d'épinettes qui semblaient avoir subi très peu de perturbations. Le mélèze avait une croissance en hauteur nettement supérieure à celle de l'épinette jusqu'à l'âge de 65 ans.

\section{Introduction}

Eastern larch or tamarack (Larix laricina (Du Roi) $\mathrm{K}$. Koch) is a common species throughout the boreal forest of Canada, particularly on lowland sites where it is a common associate of black spruce (Picea mariana (Mill.) B.S.P.). Eastern larch has historically been used on a limited scale in Canada for products such as fencing and railroad ties, where resistance to decay is an important attribute. It has not been used to a significant degree as a pulpwood species because of difficulties in using the wood in existing pulping processes and because there has been an abundant supply of more desirable species such as black spruce, white spruce (Picea glauca (Moench) Voss), jack pine (Pinus banksiana Lam.) and balsam fir (Abies balsamea (L.) Mill.).

Eastern larch has, as a consequence, not received much attention from forest researchers. In particular, growth data is difficult to find. The data available are either based upon young plantations or subjective observations (Anonymous 1977, Cook 1941, Beeftink 1951, Roe 1952, Fowells 1965). The work with plantations has indicated that early height growth of eastern larch greatly exceeds its common conifer associates on both upland and lowland sites following planting. However, long term growth rates relative to other conifers, and in particular its most common associate, black spruce, appear to be unavailable.

1This study was funded in part by Lakehead University's Canadian Forestry Service Block Grant.
This paper presents the results of a small study comparing growth rates of black spruce and eastern larch from two sites in northwestern Ontario.

\section{Methodology}

Two stands with a larch-black spruce mixture were located near Thunder Bay on Crown lands. One stand is located approximately $56 \mathrm{~km}$ southwest of Thunder Bay near the Jarvis River. The area is close to Lake Superior and had been cut over around the turn of the century. The trees selected for this study were located in leave strips from a second harvest which occurred about 1972. The stand is located on relatively flat terrain with a deep (50-80 cm) layer of mosses and organic matter overlying a heavy clay soil. The second stand is located approximately $80 \mathrm{~km}$ northwest of Thunder Bay near Mott Lake. It is relatively flat and has a deep organic soil. The site has never been logged. Both sites were characterized by a water table $30-40 \mathrm{~cm}$ below the surface.

At least nine dominant or co-dominant trees of each species were felled at each location. The trees were selected with the intent of sampling only undamaged specimens which had not been subject to an edge effect. Each of the trees was measured for total height and sectioned at .3 metres, 1.5 metres, and every 2 metres thereafter to a top diameter of $4-5 \mathrm{~cm}$. Tree ages were estimated by adding three years to the ring count at .3 metres.

The age-height data was determined using standard stem analysis techniques. The data for each species at each location was analyzed using linear regression.

\section{Results}

The height-age relationships for the larch and spruce are shown in Figure 1. It is clear that growth rates of the larch substantially exceed the black spruce on both sites. The Mott Lake site is Ontario site class la for black spruce. The Jarvis River site is Ontario site class $\hat{i}$ for black spruce (Plonski 1974). This translates to site indexes of approximately $14 \mathrm{~m}$ (45 feet) and $12 \mathrm{~m}$ (40 feet), respectively, at age 50 .

A linear regression analysis of the data shows the differences in growth rates between the two species. However, being a straight line relationship, it doesn't show what appears to be a converging of the growth trends beginning at about age 50 (Figure 1). 

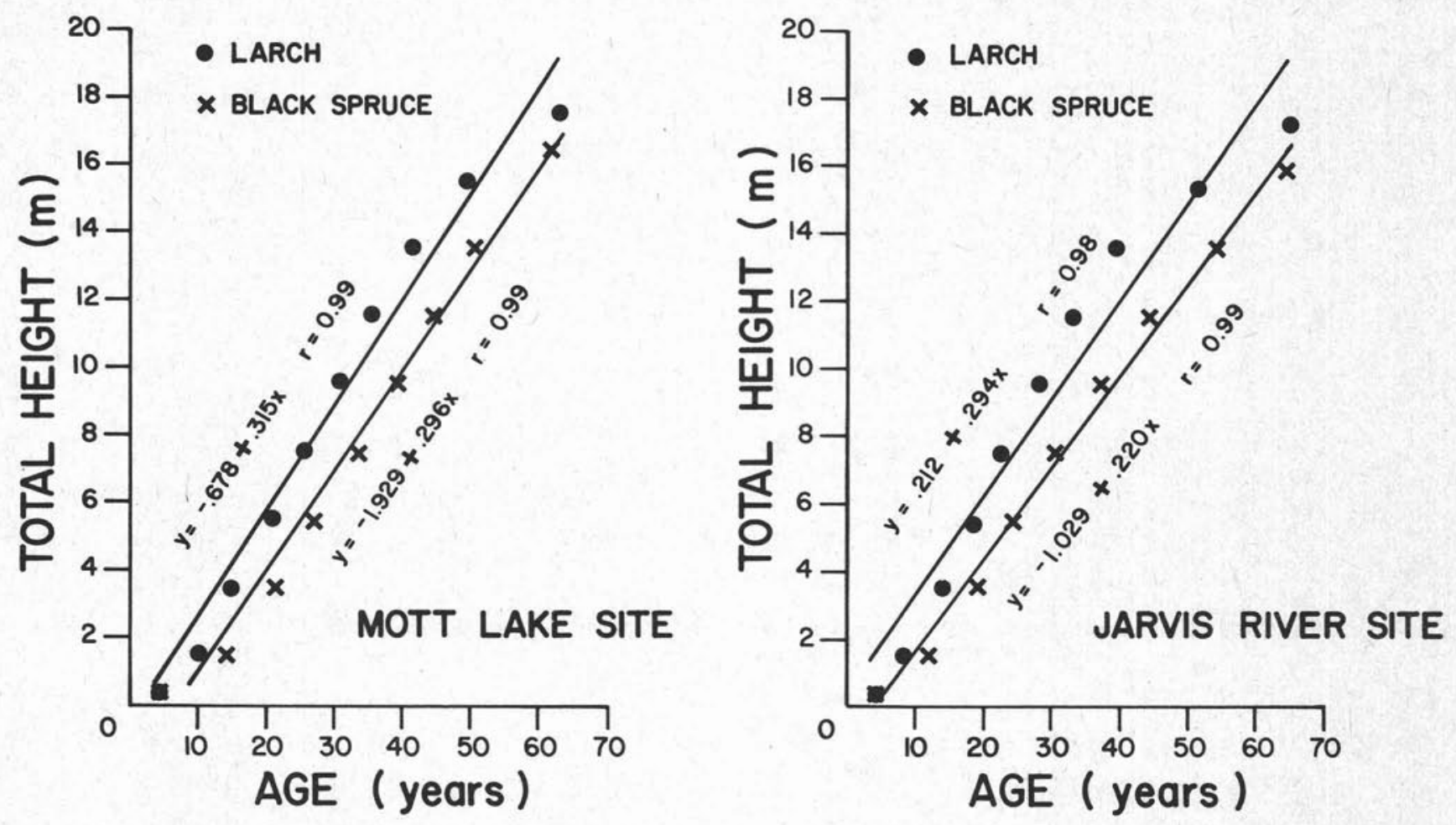

Fig. 1. Relationship of total Height to age for eastern larch and black spruce on two sites in northwestern Ontario. Based on nine trees of each species from each site. Plotted points represent mean ages (assumed 3 years at $.3 \mathrm{~m}$ ) at uniform heights as determined by stem analysis.

\section{Discussion and Conclusions}

The data from this study shows a distinct growth differential between eastern larch and black spruce growing on the same sites and, in general, subjected to the same growing conditions.

While this study supports the general belief that larch exhibits better growth rates than its conifer associates, the results cannot be extrapolated to other species, nor to different site conditions. In the plantation trials previously cited, larch generally exhibited superior early growth rates on all sites in relation to other native conifers and exotic larches. However, experience has shown that early responses are not always reliable indicators for long term results. A complicating factor is that while there is evidence that eastern larch grows well on upland sites, it does not commonly occur on these sites naturally. Eastern larch requires an almost continuously moist seedbed for young seedlings to survive (Duncan 1954). For this reason, data on larch growth on upland sites will be very difficult to obtain by methods other than long term experimental plantings. The prospects do seem promising, however.

The data in this study does not indicate which of these two species can produce more wood fibre on a per hectare basis in the long run. The larch was taller and larger in diameter (bh) than the spruce at Jarvis River but taller and equal in diameter at Mott Lake (larch $-20.1 \mathrm{~cm}$.; spruce $-18.2 \mathrm{~cm}$ at Jarvis River and larch $-19.2 \mathrm{~cm}$.; spruce $-19.3 \mathrm{~cm}$. at Mott Lake). Also, it is possible that even though individual tree volume growth may be superior for larch, its intolerance may make it less productive on a per hectare basis.

This limited study supports the widely held, but essentially unproven, belief that eastern larch has greater long term growth potential than its common coniferous associates. The full potential of eastern larch on a variety of sites, vis-à-vis other conifers, will only be determined after substantial further research. It seems likely that the ground swell of enthusiasm for larch, combined with growing interest in heretofore undesirable species, will guarantee that eastern larch will receive much more attention in the future.

\section{References}

Anonymous. 1977. Comparison of the early growth of Larix and Picea in plantations in Newfoundland, Forestry Service. Fisheries and Env. Can. Vol. 33, No. 2: 13-14.

Beeftink, H. H. 1951. Some observations on tamarack or Eastern larch (Larix laricina Du Roi (Koch) in Alberta. For. Chron. 27: 38-39.

Cook, D. B. 1941. Five seasons' growth of conifers. Ecology 22: 285-296.

Duncan, D. P. 1954. A study of some of the factors affecting natural regeneration of tamarack (Larix laricina) in Minnesota. Ecology 35: 498-521.

Plonski, W. L. 1974. Normal Yield Tables (Metric) for Major Forest Species in Ontario. Div. of For., Ont. Min. of Nat. Res.

Roe, E. I. 1952. Comparative height growth of native conifers in northeastern Minnesota. USFS. Lake States F.E.S. Tech. Note 389 . 